\title{
The Investigation of Purchase Intention in Using Skincare Product Aloe Vera 92\% Shooting Gel Nature Republic in Surabaya City
}

\author{
Denis Fidita Karya ${ }^{1}$, Mohamad Yusak Anshori ${ }^{2}$, Syeh Rotul Azizah ${ }^{3}$, Teguh \\ Herlambang ${ }^{4}$ \\ 1,2 Management Department, University of Nahdlatul Ulama Surabaya \\ ${ }^{3}$ Postgraduate School, University of Nahdlatul Ulama Surabaya \\ ${ }^{4}$ Information System Department, University of Nahdlatul Ulama Surabaya
}

Corresponding author. Email: denisfk@unusa.ac.id

\begin{abstract}
This study aims to determine how significant is the influence of Korean Wave, eWom, and Country of Origin variables on Purchase Intention; Through Brand Image as a Mediation Variable (Study on Purchasing Aloe Vera 92\% Shooting Products Nature Republic Gel in the City of Surabaya). The research method used in this study is the questionnaire method, that is, by distributing questionnaires based on the research objectives. The number of respondents taken for the research is 265 respondents. Using the non-probability sampling method with a purposive sampling approach, and the method used in analyzing the data in this study is SmartPLS 2.0. Based on the data analysis, the results show that the Korean wave does not have a significant effect on brand image, but it has a significant positive effect on purchase intention. Country of origin has a significant positive effect on brand image and purchase intention. eWom has no significant positive effect on brand image and purchase intention. Brand image has a significant positive effect on purchase intention. While the mediation results show that brand image is able to mediate the country of origin in the purchase intention of Aloe Vera 92\% Nature Republic Gel Shooting, but cannot mediate Korean wave and eWom on purchase intention of Aloe Vera 92\% Nature Republic Gel.
\end{abstract}

Keywords: Korean wave, Country of Origin, eWom, Brand Image, Purchase Intention.

\section{INTRODUCTION}

At present, the need to beautify oneself has become a priority, both physically and non-physically beautiful, especially the facial skin. A clean and beautiful face is every woman's dream. To maintain and support physical beauty, especially the facial skin, Indonesian women choose to use cosmetics routinely. Cosmetics today are a phenomenal product and are a primary need especially for women who want to beautify and make treatment on their faces. The national cosmetics industry recorded the growth of the Indonesian cosmetics industry increasing by $20 \%$ in 2018 with a total sales value of 22.8 trillion [28].

Based on the data in table 1 , the increase in the cosmetics industry in 2018 was $20 \%$. From year to year the development of cosmetics in Indonesia is always increasing. This proves, Indonesia is a potential market for beauty industry entrepreneurs from both outside and within the country, so the potential is utilized by businessmen to develop their business ventures in the cosmetics field, but also to increase industrial profits [1];[2] and company share ownership [3];[4];[5]. 
Table 1 The growth of cosmetics industry market in Indonesia for 2014-2018

\begin{tabular}{|l|l|l|}
\hline Year & \multicolumn{1}{|c|}{$\begin{array}{c}\text { Market } \\
\text { (Rp Triliun) }\end{array}$} & \multicolumn{1}{|c|}{$\begin{array}{c}\text { Increase } \\
(\%)\end{array}$} \\
\hline 2014 & 12.8 & - \\
\hline 2015 & 13.9 & $8,6 \%$ \\
\hline 2016 & 17 & $22,3 \%$ \\
\hline 2017 & 19 & $11,8 \%$ \\
\hline 2018 & 22.8 & $20 \%$ \\
\hline
\end{tabular}

Source: GBG Indonesia, 2018

For Indonesian women the word 'beautiful' is still seen from the physical aspect like the skin (face) that is clean, bright, and glowing. So, to realize this dream, women prefer to use skincare on a daily basis and use a variety of skincare products considered as something more important than just using makeup.

Nature Republic is a cosmetics company established in Korea in 2009. Currently, the Nature Republic brand has existed in 17 countries, one of which is in Indonesia. This product received a good response from consumers due to the Korean cultural trend commonly called the Korean wave effect. Like what was said by [6] one's perception of the Korean state through the Korean Wave will lead someone to have a good perception of the brand originating from South Korea.

Based on the website soompi.com quoted from $\mathrm{CeCi}$ magazine, one of the leading magazines in Asia, released the 2015 K-Beauty Award and named Aloe Vera 92\% Shooting Gel Nature Republic as The Best Selling Body Product [7] Judging from the data above, Nature Republic has got attention of the cosmetics lover community in Indonesia, especially to Aloe Vera 92\% Shoothing Gel products even though Nature Republic only had an official store in Indonesia in 2018. The absence of an official store, does not make it difficult for consumers to buy this product.

Nature Republic Aloe Vera $92 \%$ Shoothing Gel is a skincare product from Nature Republic. Aloe Vera 92\% Shoothing Gel can be used for various types, ranging from facial treatments (skincare), body care, and hair care. This product is suitable for all skin types, especially sensitive skin types because of its high oxygen content of $92 \%$. So, we can be sure this product uses natural ingredients. Although many types of cosmetic products use the same concept, Nature Republic can compete with other cosmetic products. The number of users of the Nature Republic skincare brand, especially the Aloevera 92\% Shoothing Gel product made from the basic ingredients (aloe vera), causes many competitors to make similar products.

The results of previous studies show that consumers or buyers of Korean cosmetics initially saw Korean films or dramas causing a sense of interest. The interest is triggered by the players or actors with clean and white skin or commonly referred to as glowing. So with the advent of Korean cosmetics it is very easy to market it to consumers. Before making a purchase, consumers will first find out how review or experience of other consumers who have used on the product, especially on the new products. In the current modern era, such information can be easily obtained not only by face to face but also bu word of mouth, as well as through blogs and YouTube providing skincare reviews, meaning that the information can be obtained very easily.

E-Wom was an online word of mouth such as reviews on blogs and also on YouTube [8]. E-Wom was recognized as having a very large role in influencing and shaping consumer attitudes and purchase intentions. Many researchers showed that e-Wom was more influential, and very effective in the marketing process, and was also able to provide benefits to companies [9]. Negative and positive reviews on the product determine whether or not the product is suitable for use. The number of positive reviews will affect the brand image of a product. The information will influence to support sales afterwards, and encourage potential new customers to make purchasing decisions. When potential customers have obtained information about a product from previous consumer experience, the new prospective customers will draw conclusions whether the product is suitable for use or not.

Other determinants in influencing consumers to buy a product or service can be influenced by the image of a product. This image is not as easy as printing goods in a factory, but this image is formed from what has been obtained in accordance with one's understanding, experience, and knowledge about the product. [10] revealed that the image of the brand had a relationship with consumer attitudes in the form beliefs and preferences for a brand. A positive image of a brand enables consumers to make purchases. Assessments made by consumers for a product are based not only on the results of positive reviews, attractiveness, and physical characteristics of the product, but also on the country that produced it (Country of Origin). According to [11] Country of origin is part of brand image and influences brand value. Country of origin is also referred to as an attribute in making purchasing decisions because the image of a product can be seen from the country of origin. [12] revealed that brand image is a group of brand associations formed and attached to consumers' minds. The location of a product where the product is produced affects consumer perceptions about the quality of the product.

\section{CONCEPTUAL MODEL}

Korean Wave is a fondness for Korean dramas, films, and Korean pop. Korean wave, called hallyu, is one of the popular cultural phenomena from Korea 
widely spread through mass media, and its popularity has spread to the Asian region [13]. The likability of Korean celebrities, Korean television dramas, and Korean popular music has a positive effect on Korean image. Therefore, it can turn into a positive image of Korean brands [6]. When someone is affected by the Korean wave, it can be said that someone likes one of Korean dramas, Korean celebrities, or Korean music. Actors and actresses playing roles in Korean dramas are always described as having a fresh and cool appearance, having white skin and beautiful or handsome faces. Not only Korean dramas, but also girl bands and boy bands from Korea have beautiful and handsome faces. This makes many people like people of Korea. The good looks possessed by Korean people acting in films, or playing music make many people think that beauty products made in South Korea make a person become handsome too.

According to [14], country of origin is often associated with product quality. Whereas [15] shows that consumers tend to use national origin if consumers are not familiar with product brands. According to [16] brand image is a multidimensional concept of which consumers can have different opinions based on information known about the brand itself. There are many dimensions that can affect this, such as quality, style/model, durability, and others that also affect overall product evaluation. So, it can be interpreted if consumers want to buy an unfamiliar product, they can measure it through several dimensions, and one of them is the image of the country or country of origin. The better the image of the country of origin, the better the consumer's thinking about the product.

According to[17], e-Wom is a negative or positive statement made by actual, potential or previous consumers about a product or company where it is available to everyone via internet social media. When considered the better the eWom, the better the brand image of a brand, it is because e-Wom is a medium for conveying various information and for engaging in conversation with many people through the web or blog. [17] and [18] show that e-Wom has a significant impact on brand image.

Brand image is the consumer perception of a brand, reflected in the brand association held in the consumer memories. Brand image plays an important role in improving the performance of a company because brand image is an indirect tool able to change consumer buying behavior [19]. The impact of brand image on purchase intention is that, if a company already has a good brand image and has implanted the brand image in the minds of consumers, the company does not need to struggle to find who will be its customers, because with a good brand image, consumers will be confident of the brand [20] So, it can be said that a persons buying interest starts from seeing a brand image that is in accordance with consumers perceptions, and with the high brand image of the product or service, consumers increasingly believe in the product and will trigger the purchase interest. Based on the study of [21] examining the direct effects of store image and service quality on brand image and purchase intention for private label brands, and concluding that store image and brand image have a positive effect on purchase intention.

Korean Wave is a fondness for Korean dramas, films, and Korean pop. Korean wave, called hallyu, is one of the popular cultural phenomena from Korea spread through mass media, and its popularity has spread to the Asian region. Korean wave has a positive effect on exports of products from Korea. If someone likes Korean movies, drama or music, then most likely that person will buy products related to such things as CDs, concert tickets and so forth. Based on the research conducted by [22] shows that the majority of fans or fans of Korean culture prefer buying beauty products originating from South Korea. This can be influenced through their perceptions that the quality of Korean beauty products are better. E-Wom is a means of communication, although not done verbally, and possibly having no direct effect, has a permanent advantage. As internet users develop, e-Wom affects product brands on the internet and has an impact on consumer purchasing decisions [8]. Based on the research by [17], e-Wom has a significant impact on purchase intention.

\section{Result and Discussion}

THE hypothesis testing in this study was conducted by looking at the value of T-Statistics and the value of P-Values. The research hypothesis was accepted when the P-Values value was $<0.05$. The following are the results of the hypothesis testing obtained in the study through the inner model.

\begin{tabular}{|l|l|l|}
\hline \multicolumn{1}{|c|}{ Variable } & P Values & Results \\
\hline $\begin{array}{l}\text { Korean Wave -> Brand } \\
\text { Image }\end{array}$ & 0.107 & Rejected \\
\hline $\begin{array}{l}\text { Country of Origin -> Brand } \\
\text { Image }\end{array}$ & 0.000 & Accepted \\
\hline E-Wom -> Brand Image & 0.054 & Rejected \\
\hline $\begin{array}{l}\text { Brand Image -> Purchase } \\
\text { Intention }\end{array}$ & 0.002 & Accepted \\
\hline $\begin{array}{l}\text { Korean Wave -> Purchase } \\
\text { Intention }\end{array}$ & 0.000 & Accepted \\
\hline $\begin{array}{l}\text { Country of Origin -> } \\
\text { Purchase Intention }\end{array}$ & 0.001 & Accepted \\
\hline $\begin{array}{l}\text { E-Wom Purchase } \\
\text { Intention }>\text { Rejected }\end{array}$ & 0.888 & Pon \\
\hline
\end{tabular}

Based on the results of the hypothesis testing, it was concluded that the Korean wave had a positive and insignificant effect on brand image in skincare Aloe Vera 92\% Shooting Gel Nature Republic. These results indicate that Korean Wave had not effect on the 
formation of brand image. The results of the study were opposing those of the study [23] positive effect of Korean wave and brand image on Korean cosmetics of Etude House. The study took the respondents using Etude House cosmetics for less than 1 year to 2 years so they could feel the beauty of the product. Although Korean cosmetics are a part of Korea, the cultures, between Korea and Indonesia, are very different. When Korean culture is increasing among the people, Korean wave is not by cosmetics products only.

Country of origin has a significant positive effect on brand image in Aloe Vera 92\% Shooting Gel Nature Republic. Korea has a positive image in society, especially among women. Korea is able to create superior products, especially in the field of cosmetics. This is exactly what makes consumers confident about Korean cosmetic products. The various perceptions of consumers about Korean cosmetics can effect the brand image of these cosmetic products. According [11], Country of Origin is part of brand image and affects brand value. Meanwhile, [24] also said that the attitudes and beliefs of buyers towards a country affect the buying intention to a product.

Buyers' attitude and confidence of country of origin of products gives rise to an image of a brand. This means that the better the image of Korea, the better the brand image of the product of Aloe Vera 92\% Shooting Gel Nature Republic, Nature Republic company can exploit this phenomenon to improve the brand image of their products. In addition, the developed image is a major factor in country of origin, Korea is considered to have cosmetics considered capable of making glow. The image circulating that Korean products can make skin glowing like Korean actors. This reason can encourage sales of Korean products Aloe Vera 92\% Shooting Gel Nature Republic.

E-Wom had a positive but insignificant effect on brand image. Before the respondents purchased Aloe Vera cosmetics or skincare $92 \%$ Shooting Gel Nature Republic, they first checked on the review in the website or other social media. The Nature Republic website is fairly new. The more reviews obtained, the more information consumers get. Not only the number of reviews but also the results of the review affected the image. The more negative reviews, the worse the results. The e-Wom on the website is not enough to improve the brand image of the Aloe Vera 92\% Shooting Gel Nature Republic product, because the product website is fairly new. In addition to the reviews from users of Aloe Vera 92\% Shooting Gel Nature Republic, the information on a product is also considered important. When the information obtained about the product considered safe and good for the skin, then the consumers buy the product. But the information obtained about Aloe Vera 92\% Shooting Gel Nature Republic is still considered lacking, so that people need and positive purchase intention. A good brand image on cosmetic products cause consumers to make purchases, on the contrary if the brand image is bad then consumers rethink to make a purchase. The image circulating in the community that Korea has actors and people having white glowing, bright, and white skin. The existence of this image makes people want to have the same skin as the Korean people. These reasons make the sale of Aloe Vera 92\% Nature Republic Shooting Gel products increase, and so does the demand by the public. The better the brand image of a product, the greater the certainty in deciding a purchase. The brand image of the Aloe Vera 92\% Shooting Gel Nature Republic, skin care product with good quality, attractive design, and effect work effectively makes consumers more confident to make a purchase.

According to [25], the impact of the Korean wave can produce a positive image on Korean products which will ultimately lead to buying interest. If someone likes Korean dramas, films or music, Korean celebrities, then that person is most likely to buy products related to them such as movie CDs / DVDs, concert tickets, and other products displayed or used in the drama or the Korean celebrity. Fans of Korean actors will buy items promoted by their idol artists. Factors of brand ambassadors from cosmetic products are considered to be able to determine the sale of a product. Fans want to have the same items as their idols, so it's not surprising that people buy things similar to their idols. This shows that the actual phenomenon in society can influence consumers' purchasing decisions. The increasing phenomenon of the Korean wave can lead to a sense of interest in buying Aloe Vera 92\% Shooting Gel Nature Republic skincare products.

Country of Origin has a positive effect on purchase intention. The respondents agreed that Korea is a country that innovates in the manufacture of cosmetics or skincare. Korea is also a country maintaining its quality in the manufacture of cosmetics so that the respondents believe in cosmetic products made by that country, one of which is Aloe Vera 92\% Shooting Gel Nature Republic. It can be concluded that the respondents in deciding to purchase Aloe Vera 92\% Shooting Gel Nature Republic skin care products also looked at the country of origin of the product or the Country of Origin, South Korea. The indirect effect derived from the brand image in the study is greater than the direct effect that arises. That causes Country of Origin to have a dominant influence in deciding on a purchase, and brand image also has the influence on the consumers in making a purchase decision for Aloe Vera 92\% Shooting Gel Nature Republic skin care products even at lower level. In addition, Korea has beauty products in demand by the global market, moreover Korean beauty products have innovations that make people interested. Korean beauty products have 
ingredients able to make skin white and clean, so consumers will buy the product. Moreover, the perception of people saying that beautiful standards are white, with this perception the dominant community sees that Korean products can make skin whiter than other products.

E-Wom had a positive but insignificant effect on purchase intention. These results were in line with the research conducted by [26] stating that e-Wom has no significant effect on purchase intention. This is supported by the many people saying positive or negative things on the internet or social media about these products. The more negative things said on the internet and social media about skincare Aloe Vera $92 \%$ Shooting Gel Nature Republic, the worse e-Wom, and the less increase in purchasing interest, and vice versa. Aloe Vera 92\% Shooting Nature Gel products considered new in Surabaya require a review and public confidence that the product is safe to use. It could be that when consumers want to buy the product, evaluations made by the consumers having used it are few or incomplete. It is necessary to evaluate the product and introduce the product to the public by disseminating information and ingredients containing the cosmetics Aloe Vera 92\% Shooting Gel Nature Republic.

\section{CONCLUSION}

In accordance with several indicators on the questionnaire distributed to the respondents, one of which could increase the consumer purchase intention, namely the Korean Wave. Korean consumers became more consumptive of Korean products because they like Korean culture. The Aloe Vera 92\% Shoothing GelNature Republic was able to exploit this phenomenon to spread the product to other cities. In addition, it is necessary to add a review of the use of Aloe Vera 92\% Shoothing Gel Nature Republic for customers having used it, making it easier for new customers who want to try to use the product.

\section{REFERENCES}

[1] Anshori, M. Y., and Herlambang, T. 2019, "Estimation Of Profitability Of A Company In PT. ABC Using Kalman Filter", The $1^{\text {ST }}$ International Conference On Bussines, Law, And Pedagogy, 13-14 February 2019

[2] Anshori, M. Y., Herlambang, T, Karya, D.F, Muhith, A., Rasyid, R.A., 2019, Profitability Estimation of A Company In PT.ABCD Using Extended Kalman Filter,The Third International Conference on Combinatorics, Graph Teory and Network Topology, University of JemberIndonesia, 26-27 Oct 2019
[3] Karya, D.F., Katias, P., Herlambang, T., and Rahmalia, D. 2018. "Development of Unscented Kalman Filter Algorithm for stock price estimation", The Second Internatonal Conference on Combinatorics, Graph Teory and Network Topology, University of Jember-Indonesia, 24-25 Nov 2018, Journal of Physics: Conf. Series 1211 (2019) 012031

[4] Karya, D.F., Puspandam, K. and Herlambang, T., 2017. "Stock Price Estimation Using Ensemble Kalman Filter Square Root Methods", The First Internatonal Conference on Combinatorics, Graph Teory and Network Topology, University of Jember-Indonesia, 25-26 Nov 2017, Journal of Physics: Conf. Series1008 (2018) 012026.

[5] Karya, D.F., Anshori, M. Y , Mardhotillah, R.R., Puspandam, K., Muhith, A., and Herlambang, T., 2019, Estimation of Crude Oil Price Using Unscented Kalman Filter,The Third International Conference on Combinatorics, Graph Teory and Network Topology, University of JemberIndonesia, 26-27 Oct 2019

[6] Bumjun, L., Sunny, H and Kim, D. 2014. Celebrities, Dramas and Music on Preferences for Korean Restaurants: A Mediating Effect of A Country Image of Korea. International Journal of Hospitality Management, Fortcoming.

[7] K.Do. 2015. Pemenang K-Beauty Award 2015. Diakses dari http://soompi.com/article/814691wpp/koreanbeauty-brand-reveal-their-best-selling-products. Diakses pada tanggal 20 November 2019.

[8] Xiao, Z., Zhang, J., Li, D and Samutachak, B. 2016 "The Effect Of E-WOM On Country Image and Purchase Intention: An Empirical Study On Korean Cosmetic Products In China". International Journal. Services Technology and Management, Vol. 22, No 1/2.

[9] Adi, P. H., Wihuda, F., and Adawiyah, W. R. 2017. The Role of Social Media Browsing Intention of Behavioral Outcomes of Young Consumers. Market. Vol 29, No 1.

[10] Yunus, N. S. N. M., and Rasyid, W. E. W. 2016. The Influence Of Country of Origin On Consumer Purchase Intention: The Mobile Phones Brand From China. Procedia Economics and Finance. Vol.37, No 16.

[11] Keegan, W. J. and Green, M. C. 2013. Global Marketing. Harlow: Pearson.

[12] Rangkuti, F. 2014. The Power of Brand. Cetakan Kedua PT. Gramedia: Jakarta.

[13] Lestari, H., Sunarti., Bafadhal, A.S. 2019. Pengaruh Brand Ambassador Dan Korean Wave Terhadap Citra Merek Serta Dampaknya Pada Keputusan Pembelian. Jurnal Administrasi Bisnis (JAB). Vol 66, No 1. 
[14] Sanyal, S. N and Saroj, K. D. 2011. The Effect of Country Origin on Brand Equity: An Empirical Study on Generic Drugs, Journal of Product \& Brand Management, Vol. 20, No. 2: 130-140.

[15] Kotabe, M \& Helsen, K. 2010. "Global Marketing Management" (5 ${ }^{\text {th }}$ Edition). United States: Wiley.

[16] Vianita, S dan Febrina, R. 2014. Pengaruh Country of Origin Terhadap Brand Image Kosmetik Korea Selatan Pada Mahasiswi Program Sarjana FISIP UI (Studi Pada Pembelian Online dan Offline Merek Etude House.

[17] Jalilvand, M. R and Samiei, N. 2012. The Effect of Electronic Word of Mouth on Brand Image and Purchase Intention. Marketing Intelligence \& Planning Journal, Vol. 30 Issue: 4, pp.460-476.

[18] Xuan, S. Y and Lai, C. C. 2017. Electronic Wrod Of Mouth, Expreriential Marketing, Brand Image, Brand Loyalty, Purchase Intention: A Study Of Innisfree. Int. Journal of Information Technology and Business Management, Vol 60. No 1.

[19] Malik, M. E., Ghafoor, M. M and Iqbal, H. K. 2013. Impact Of Brand Image And Advertisement On Consumer Buying Behavior. World Applied Sciences Journal. (23).

[20] Permana, M. S and Haryanto, J. O. 2015. Pengaruh Country Of Origin, Brand Image Dan Persepsi Kualitas Terhadap Intensi Pembelian. Jurnal Manajemen. Vol 18, No 9.

[21] Wu, P. C. S \& Wang, Y. C. 2011. The Influence Of Electronic Word Of Mouth Message Appeal and Message Source Credibility On Brand
Attitude. Asia Pacific Journal Of Marketing And Logistics. Vol 23, No 4.

[22] Kozakhmetova, D. 2012. Sof Power Of Korean Popular Culure; K-Pop Avid Fandom in Tokyo. Lund University.

[23] Srihartati, E and Abdillah, Y. 2018. Pengaruh Korean Wave dan Country of Origin Terhadap Brand Awareness dan Brand Image Kosmetik Korea (Survei pada Mahasiswa S1 Fakultas Ilmu Administrasi Universitas Brawijaya Konsumen Produk Kosmetik Etude House. Jurnal Administrasi Bisnis.

[24] Kotler, P and Keller, K. L. 2016. Marketing Management. Edisi 15. Pearson Pretice Hall, New Jersey.

[25] Yook, E. L., Young-ok, Y and Kim, S. J. 2014. The Effects of Hallyu (Korean Wave) on Korean Transnationals in the U.S. Asian Communication Research. Volume 3. No.9

[26] Kala, D and Chaubey, D. S. 2018. The Effect of eWom Communication on Brand Image and Purchase Intention Towards Lifestyle Products in India. International Journal of Services, Economics and Management, Vol. 9, Issue 2, pp.143-157.

[27] Hair, J.F., Hult, G.T., Ringle., \& Sarstedt, M. 2014. A Primer On Partial Least Squares Structural Equation Modelling (PLS-SEM). Vol 60. No 70.

[28] Investor Daily. 2018. Industri Kosmetik Nasional Tumbuh 20\%. Diakses dari http://kemenperin.go.id/artikel/18957/IndustriKosmetik-Nasional-2018. 